\title{
Lost Generations? Indigenous Population of the Russian North in the Post-Soviet Era
}

\author{
Andrey N. Petrov \\ University of Toronto \\ andreyn.petrov@utoronto.ca
}

\begin{abstract}
This paper discusses key findings concerning population dynamic of the Indigenous minorities living in the Russian North during the post-Soviet period, highlighted by the 2002 Census. The paper places recent demographic trends into the context of past and current economic, social and institutional changes. It also provides comparisons with Indigenous population dynamics in other parts of the Arctic. Although most Indigenous peoples of the Russian North were growing numerically, they still experienced effects of Russia's economic crisis, primarily reflected in rapidly falling fertility and rising mortality in the middle-age cohorts. In addition, both the ethnic drift and legal changes seriously contributed to the population dynamic.
\end{abstract}

Key words: Indigenous peoples, Russia, population dynamics

\section{Résumé}

Cet article discute les résultats clés concernant la dynamique des populations des minorités indigènes vivant dans le nord de la Russie dans l'ère post-soviétique, ainsi que soulignés dans le recensement de 2002. Cet article place les récentes tendances démographiques dans le contexte des changements économiques, sociaux, et institutionnels passés et présents. Il apporte aussi des comparaisons avec d'autres dynamiques de populations indigènes dans d'autres régions de l'Arctique. Bien que la plupart des peuples indigènes voyaient leurs nombres augmenter, ils ressentaient quand même les effets de la crise économique en Russie; ceci se reflétait surtout dans les taux de fertilité en baisse rapide et les taux de mortalité en hausse dans la population d'âge mur. De plus, la migration ethnique et les changements légaux ont eu un impact important sur la dynamique des populations.

Mots-clés: Peuples indigènes, Russie, dynamique des populations 


\section{Introduction}

In October of 2002, thirteen years after the last Soviet census, Russia held its first census as an independent state. Census 2002 gives a long-overdue opportunity to conduct a thorough assessment of population dynamics in post-Soviet Russia. Although the overall trend of these changes was expectedly negative due to the continuing and well-documented demographic crisis (Heleniak, 1995; Semenov and Petrov, 2001), the census provided a new insight into a wide spectrum of demographic problems, not the least of which is the survivability of the Indigenous ethnic groups.

In the last century, the Indigenous peoples of the Russian North, especially minority groups, (or "the Indigenous numerically small peoples of the North" [IN$\mathrm{SPN}]$ ), by any account, have had very troubled history and have been facing formidable challenges (Pika and Prokhorov, 1988, Shnirelman, 1994; Diatchkova, 2001). Collectivization, forced sedentarization, and intensive assimilation in the Soviet period followed decades of diseases and poverty in the 19th century (Poelzer and Fondahl, 1997). Along with assimilation, the unusual problem of a demographic "stalemate" surfaced later in the 1970s. The Indigenous peoples experienced a halt in the process of demographic transition: while fertility rates were slowly in decline, mortality failed to recede to the expected levels. The source of this pattern was also unusual. Although better medical care and socioeconomic conditions predictably reduced infant mortality, extraordinarily high death rates in the middle-age cohorts were responsible for the shrinking natural growth and low life expectancy. These problems prompted some researchers in the 1970s to suggest that the Indigenous peoples of the Russian North were approaching extinction. Although this pessimistic scenario has not come true, the Indigenous peoples still face serious challenges preserving their populations and cultures (Pika and Prokhorov, 1988; Bogoyavlensky, 1994; 2004; Ziker, 2002).

The main objective of this paper is to review and discuss the population dynamic and the changes in the demographic structure of Indigenous minorities (INSPN) in the context of cultural, economic, and social transformations experienced by different generations of Indigenous people in the post-Soviet period. This discussion will also be informative for a wider debate about the demographic viability of Indigenous ethnic groups in the Russian North, compared to their counterparts in other Arctic countries. The paper draws on census and annual statistical reports, as well as on the existing analytical studies. Particular attention is given to the Indigenous population structure anomalies associated with fundamental demographic changes and an intensive "ethnic drift" in the last few decades, as well as with the socioeconomic crisis.

\section{Data and Definitions}

"The Indigenous numerically small peoples of the North, Siberia and the Far East" are officially defined by federal law (Federal'noe Sobranie RF, 1999) as peoples of 
fewer than 50,000 individuals, which settle on the ancestrally occupied lands (homelands), maintain traditional lifestyle and activities, and regard themselves as independent ethnic groups. ${ }^{1}$ Given this definition, the INSPN comprises only numerically small Indigenous ethnic groups (Indigenous minorities). Larger peoples, such as the Yakut, Komi, and Buryat, are not included in the INSPN and are not surveyed in this paper. ${ }^{2}$ In recent years, a more careful ethnographic analysis and rising appreciation of Indigenous ethnicity has led to an increase in the officially recognized INSPN. The census of 2002 distinguished 35 INSPN $^{3}$ (Goskomstat Rossii, 2002), up from 26 in 1989. Most recently, in April of 2006, the government adopted a revised list of Indigenous minorities, which now includes 40 northern ethnic groups (Table 1). These groups enjoy special Indigenous minority rights and privileges (which are modest compared to other Arctic countries). Most data available for longitudinal comparisons, however, include the 26 ethnic groups included in both the 1989 and 2002 censuses (see Table 1). Further, the paper will largely refer to two different groupings of the INSPN: most of the following discussion deals with the INSPN-26 (used in the 1989 census) and INSPN-35 (used in the 2002 census and in most annual statistics of the late 1990s and 2000s). In the text, I will make a special note and distinction wherever necessary.

It is also important to define Native "homelands." This is methodologically crucial, because statistical data on the INSPN is typically operationalized through the notion of homelands. The list of Indigenous homelands at the rayony (county) level is approved by the Russian Government. Since 1980, this list has been changed and amended four times (1980, 1987, 1993, and 2000). In 1993, it was altered most significantly. Currently, the list includes all or most of the territories of Nenetskiy, Yamal-Nenetskiy, Khanty-Mansiskiy, Dolgan-Nenetskiy (Taimyrskiy), Evenkiiskiy, Chukotskiy, and Koryakskiy autonomous districts $(\text { okrugs })^{4}$ and parts of other regions in the European and Asiatic North. Most of these are rural areas traditionally settled by the INSPN, where they either dominate or constitute a substantial proportion of population. Throughout this paper, I refer to the Indigenous homelands in the official post-1993 interpretation, and provide a special note in other cases if necessary.

Yet another problematic subject in conducting the ethnic group-based analysis is the definition of ethnicity. According to the methodology adopted by the 2002 census of Russia, the ethnicity question was open-ended and appeared on the form filled by $100 \%$ of respondents (forms “ $K$ ” and “Д”), who reported their ethnicity based on

1. In the text, I abbreviate this official title to INSPN (Indigenous Numerically Small Peoples of the North). Sokolovski (2006) provides a useful overview of historical change in defining indigeneity and in the legal recognition of the Indigenous peoples in Russia.

2. Henceforth, I use the term "Indigenous people" to denote the INSPN only.

3. At the time, Russia officially recognized 35 ethnic groups, but the census considered Alutour together with Koryak. Out of 35 peoples, however, only 28 are geographically "northern peoples," while 7 additional ethnic groups reside in south Siberia regions.

4. In 2007, Evenkiiskiy and Taimyrskiy okrugs were amalgamated with Krasnoyarskiy kray, and Koryakskiy okrug with Kamchatskaya oblast' (now Kamchatskiy kray). 
Table 1. Census Population Count of the Indigenous Peoples of the Russian North (1926-2002)

\begin{tabular}{|c|c|c|c|c|c|c|c|c|}
\hline \multirow[b]{4}{*}{ Year of Census } & \multicolumn{8}{|c|}{ Censuses* } \\
\hline & \multicolumn{6}{|c|}{ USSR (1929-1989) } & \multicolumn{2}{|c|}{ Russia (2002) } \\
\hline & \multicolumn{6}{|c|}{ Totals } & \multicolumn{2}{|c|}{$\begin{array}{c}\text { Total }^{* *} \begin{array}{c}\text { North, Siberia, } \\
\text { and Far East }\end{array}\end{array}$} \\
\hline & 1926 & 1939 & 1959 & 1970 & 1979 & 1989 & 2002 & 2002 \\
\hline Northern Indigenous Peoples & 132549 & 143359 & 131111 & 153246 & 158324 & 184448 & 208980 & 198745 \\
\hline Nenets & 17566 & 24053 & 23007 & 28705 & 29894 & 34665 & 41302 & 40187 \\
\hline Evenk & 38746 & 29666 & 24151 & 25149 & 27531 & 30163 & 35527 & 34610 \\
\hline Khant & 22306 & 19160 & 19410 & 21138 & 20934 & 22521 & 28678 & 27655 \\
\hline Even & 2044 & 9698 & 9121 & 12029 & 12286 & 17199 & 19071 & 18642 \\
\hline Chukchi & 12332 & 13835 & 11727 & 13597 & 14000 & 15184 & 15767 & 14109 \\
\hline Nanai & 5860 & 8526 & 8026 & 10005 & 10516 & 12023 & 12160 & 11569 \\
\hline Mansi & 5754 & 6315 & 6449 & 7710 & 7563 & 8474 & 11432 & 10572 \\
\hline Koryak & 7439 & 7354 & 6287 & 7487 & 7879 & 9242 & 8743 & 8271 \\
\hline Dolgan & 650 & 3971 & 3932 & 4877 & 5053 & 6945 & 7261 & 6879 \\
\hline Nivkh & 4076 & 3902 & 3717 & 4420 & 4397 & 4673 & 5162 & 4902 \\
\hline Selkup & 1630 & 6441 & 3768 & 4282 & 3565 & 3612 & 4249 & 4056 \\
\hline Itelmen & 4217 & 1706 & 1109 & 1301 & 1370 & 2481 & 3180 & 2939 \\
\hline Ulchi & 723 & $n / d$ & 2055 & 2448 & 2552 & 3233 & 2913 & 2718 \\
\hline Saami & 1720 & 1836 & 1792 & 1884 & 1888 & 1890 & 1991 & 1769 \\
\hline Eskimo & 1293 & 1309 & 1118 & 1308 & 1510 & 1719 & 1750 & 1553 \\
\hline Udege & 1357 & 1743 & 1444 & 1469 & 1551 & 2011 & 1657 & 1531 \\
\hline Ket & 1428 & 1243 & 1019 & 1182 & 1122 & 1113 & 1494 & 1189 \\
\hline Yukagir & 443 & 507 & 442 & 615 & 835 & 1142 & 1509 & 1176 \\
\hline Chuvan & 705 & 611 & $n / d$ & $\mathrm{n} / \mathrm{d}$ & $n / d$ & 1511 & 1087 & 990 \\
\hline Tofalar & 415 & 410 & 586 & 620 & 763 & 731 & 837 & 723 \\
\hline Nganasan & 887 & 738 & 748 & 953 & 867 & 1278 & 834 & 811 \\
\hline Orochi & 647 & $n / d$ & 782 & 1089 & 1198 & 915 & 686 & 426 \\
\hline Negidal & 683 & $\mathrm{n} / \mathrm{d}$ & $n / d$ & 537 & 504 & 622 & 567 & 505 \\
\hline Aleut & 353 & 335 & 421 & 441 & 546 & 702 & 540 & 452 \\
\hline Orok & 162 & $\mathrm{n} / \mathrm{d}$ & $\mathrm{n} / \mathrm{d}$ & $n / d$ & $\mathrm{n} / \mathrm{d}$ & 190 & 346 & 298 \\
\hline Enets & $n / d$ & $n / d$ & $\mathrm{n} / \mathrm{d}$ & $n / d$ & $\mathrm{n} / \mathrm{d}$ & 209 & 237 & 213 \\
\hline
\end{tabular}

Indigenous Peoples added to the List of the Indigenous Numerically Small Peoples of the North, Siberia and the Far East after 1989***

$\begin{array}{lllllllrr}\text { Shor } & \mathrm{n} / \mathrm{d} & \mathrm{n} / \mathrm{d} & \mathrm{n} / \mathrm{d} & \mathrm{n} / \mathrm{d} & \mathrm{n} / \mathrm{d} & \mathrm{n} / \mathrm{d} & 13975 & 12773 \\ \text { Veps } & \mathrm{n} / \mathrm{d} & \mathrm{n} / \mathrm{d} & \mathrm{n} / \mathrm{d} & \mathrm{n} / \mathrm{d} & \mathrm{n} / \mathrm{d} & \mathrm{n} / \mathrm{d} & 8240 & \mathrm{n} / \mathrm{a} \\ \text { Todja } & \mathrm{n} / \mathrm{d} & \mathrm{n} / \mathrm{d} & \mathrm{n} / \mathrm{d} & \mathrm{n} / \mathrm{d} & \mathrm{n} / \mathrm{d} & \mathrm{n} / \mathrm{d} & 4442 & 4435 \\ \text { Kumanda } & \mathrm{n} / \mathrm{d} & \mathrm{n} / \mathrm{d} & \mathrm{n} / \mathrm{d} & \mathrm{n} / \mathrm{d} & \mathrm{n} / \mathrm{d} & \mathrm{n} / \mathrm{d} & 3114 & 2888 \\ \text { Soyot } & \mathrm{n} / \mathrm{d} & \mathrm{n} / \mathrm{d} & \mathrm{n} / \mathrm{d} & \mathrm{n} / \mathrm{d} & \mathrm{n} / \mathrm{d} & \mathrm{n} / \mathrm{d} & 2769 & 2739 \\ \text { Teleut } & \mathrm{n} / \mathrm{d} & \mathrm{n} / \mathrm{d} & \mathrm{n} / \mathrm{d} & \mathrm{n} / \mathrm{d} & \mathrm{n} / \mathrm{d} & \mathrm{n} / \mathrm{d} & 2650 & 2534 \\ \text { Telengit } & \mathrm{n} / \mathrm{d} & \mathrm{n} / \mathrm{d} & \mathrm{n} / \mathrm{d} & \mathrm{n} / \mathrm{d} & \mathrm{n} / \mathrm{d} & \mathrm{n} / \mathrm{d} & 2395 & 2368 \\ \text { Kamchadal } & \mathrm{n} / \mathrm{d} & \mathrm{n} / \mathrm{d} & \mathrm{n} / \mathrm{d} & \mathrm{n} / \mathrm{d} & \mathrm{n} / \mathrm{d} & \mathrm{n} / \mathrm{d} & 2293 & 2013 \\ \text { Tubalar } & \mathrm{n} / \mathrm{d} & \mathrm{n} / \mathrm{d} & \mathrm{n} / \mathrm{d} & \mathrm{n} / \mathrm{d} & \mathrm{n} / \mathrm{d} & \mathrm{n} / \mathrm{d} & 1596 & 1533 \\ \text { Chelkan } & \mathrm{n} / \mathrm{d} & \mathrm{n} / \mathrm{d} & \mathrm{n} / \mathrm{d} & \mathrm{n} / \mathrm{d} & \mathrm{n} / \mathrm{d} & \mathrm{n} / \mathrm{d} & 855 & 830 \\ \text { Chulym } & \mathrm{n} / \mathrm{d} & \mathrm{n} / \mathrm{d} & \mathrm{n} / \mathrm{d} & \mathrm{n} / \mathrm{d} & \mathrm{n} / \mathrm{d} & \mathrm{n} / \mathrm{d} & 656 & 643 \\ \text { Taz } & \mathrm{n} / \mathrm{d} & \mathrm{n} / \mathrm{d} & \mathrm{n} / \mathrm{d} & \mathrm{n} / \mathrm{d} & \mathrm{n} / \mathrm{d} & \mathrm{n} / \mathrm{d} & 276 & 256 \\ \text { Alutor } & \mathrm{n} / \mathrm{d} & \mathrm{n} / \mathrm{d} & \mathrm{n} / \mathrm{d} & \mathrm{n} / \mathrm{d} & \mathrm{n} / \mathrm{d} & \mathrm{n} / \mathrm{d} & 12 & 10 \\ \text { Kerek } & \mathrm{n} / \mathrm{d} & \mathrm{n} / \mathrm{d} & \mathrm{n} / \mathrm{d} & \mathrm{n} / \mathrm{d} & \mathrm{n} / \mathrm{d} & \mathrm{n} / \mathrm{d} & 8 & 3\end{array}$

Notes: * data for different Censuses are not equally reliable; ** total is given for 26 ethnic groups included in 1989 and 2002 Censuses (INSPN-26); ${ }^{\star \star \star}$ reflects changes effective 17 April 2006; n/d, no data available.

Sources: Rosstat, 2004b, vol. 4, 13; Bogoyavlensky, 2004; RAIPON, 2007 
their self-identification (if literally translated, the question directly asked "what is your nationality?"). The ethnicity of children was identified by parents. These principles were identical to previous Soviet censuses (Goskomstat Rossii, 2002). Such consistency makes possible direct longitudinal comparisons.

Answering the question about language proficiency, $100 \%$ of respondents were asked to indicate their ability to speak Russian and up to three other languages. It was a change from the 1989 census, where respondents were only requested to name their mother tongue (without a clear indication of the ability to speak it). In contrast, in 2002 Rosstat assigned mother tongues to every INSPN-35 group post factum: the ability of Indigenous individuals to speak their Native language was considered against the official list of mother tongues during the census data post-processing (Goskomstat Rossii, 2002:560). Also unlike preceding censuses, questions on ethnicity and language were separated on the form to avoid a possible conflation of the two by respondents.

Unlike the rest of the country, where extended census questionnaires covered only $25 \%$ of residents, the 2002 census targeted $100 \%$ of individuals residing in the Native homelands. Therefore, the census represents a unique near-100\% sample of the Native homelands population that includes data on household arrangements, demography, housing, ethnicity, language, citizenship, sources of subsistence (income), employment, socioeconomic characteristics (labour force participation, sector of employment, occupation, place of work), migration and the number of lifeborn children. It also gives complete information on people's ethnicity elsewhere in the country. ${ }^{5}$

In addition to the census, this paper incorporates information from the annually published statistical reports concerning the INSPN (Goskomstat Rossii, 1999; Rosstat, 2005). Unfortunately, these annual Rosstat datasets include information only on the INSPN living in their homelands. Moreover, due to the data collection limitations, many variables are given only for the Indigenous population residing in rural areas. This creates some problems with reconciling annual figures with census results. The longitudinal comparability of yearly statistics is further undermined by frequent changes in definitions of both the INSPN and their homelands. However, the scope of these variations is limited, and does not make year-to-year comparisons impossible.

\section{Population Change and its Sources}

Three major points are to be mentioned when discussing population change among the INSPN. First, taken in total, the Indigenous population of the Russian North demonstrated a steady growth over the last several decades (Table 1). In October

5. Certainly, many experts expressed strong reservations about the accuracy of 2002 census. There are allegations of fraud and misrepresentation of results, as well as of failure to collect information about a substantial portion of Russia's population (see details in Heleniak, 2003). 
2002 , the INSPN-35 reached the 243,000 population mark, including 209,000 for the original 26 INSPN. The latter figure can be compared to 181,500 INSPN-26 in 1989 and 153,200 INSPN-26 in 1979. Northern Indigenous minorities, however, constituted only $0.16 \%$ of Russia's total population.

Second, the dynamic of the Indigenous population depended on both natural growth and "non-demographic" factors (Figure 1). "Non-demographic" determinants included legal changes or shifts in ethnic self-identification by individuals (i.e., the "ethnic drift"). Historically, the assimilation factor was remarkably strong for almost all northern Indigenous minority groups, reducing the population growth by $70 \%$ in $1970-1978$ and $12.0 \%$ in $1979-1989$. In contrast, reclaiming Indigenous ethnicity and other "non-demographic" factors contributed to INSPN-26 growth by $5.5 \%$ in 1989-2002 (Bogoyavlensky, 2004).

Finally, both demographic and assimilation-driven population changes significantly differed from one Indigenous nation to another. According to the 2002 census, some groups experienced big gains in population, in particular Nenets, Khant, Evenk, and Mansi (Tables 1 and 2, Figure 1). Other northern peoples demonstrated substantial losses, such as Nganasan (partly attributable to errors in the 1989 census), Orochi, Aleut, and Ulchi (Tables 1 and 2). Population numbers of many INSPN-26 remained essentially the same as they were in 1989. This differentiation stems from dissimilarities in the natural growth and nondemographic factors among these groups. ${ }^{6}$

Annual statistics indicate that over the entire period between 1989 and 2002, only 2 of 26 northern Indigenous nations experienced natural decline (Bogoyavlensky, 2004). However, after the socioeconomic crisis fully unfolded, there were already 12 depopulating groups in 1995-2000 (Tishkov and Stepanov, 2004). ${ }^{7}$ The analysis based on detailed statistical reports available since 1996 (Goskomstat Rossii, 1999, Rosstat, 2005), confirms the latter observation: 12 Indigenous groups have experienced natural decline between 1996 and 2004, including 9 having persistent natural loss throughout these years. Such depopulation is a deeply abnormal demographic event, given that the INSPN have not completed stage three of the demographic transition.

A comparison between the census population figures and population estimates, based on natural growth between 1989 and 2002, showed substantial discrepancies that can be largely attributed to ethnic drift. Bogoyavlensky (2004) demonstrated that as many as 12 Indigenous ethnic groups between 1989 and 2002 grew mostly due to "nondemographic" sources ${ }^{8}$ (Figure 1). Some beneficiaries of ethnic drift were

6. The intergroup differentiation in the post-Soviet period can be largely attributed to nondemographic sources (ethnic drift and legal recognition) of change (they explain $92.1 \%$ of variance). This observation highlights the impact of institutional reforms in the Russian North after 1991.

7. However, these two analyses slightly differed in their spatial coverage: regions of the "Extreme North" vs. regions of "traditional settlement of Indigenous peoples" (i.e., the homelands).

8. Unfortunately, the annual natural growth statistics for the entire period between 1989 and 2002 are not available. Bogoyavlenskiy used unpublished Goskomstat materials. Moreover, his analysis of 
Figure 1. Sources of change in the Indigenous Population, 1989-2002.

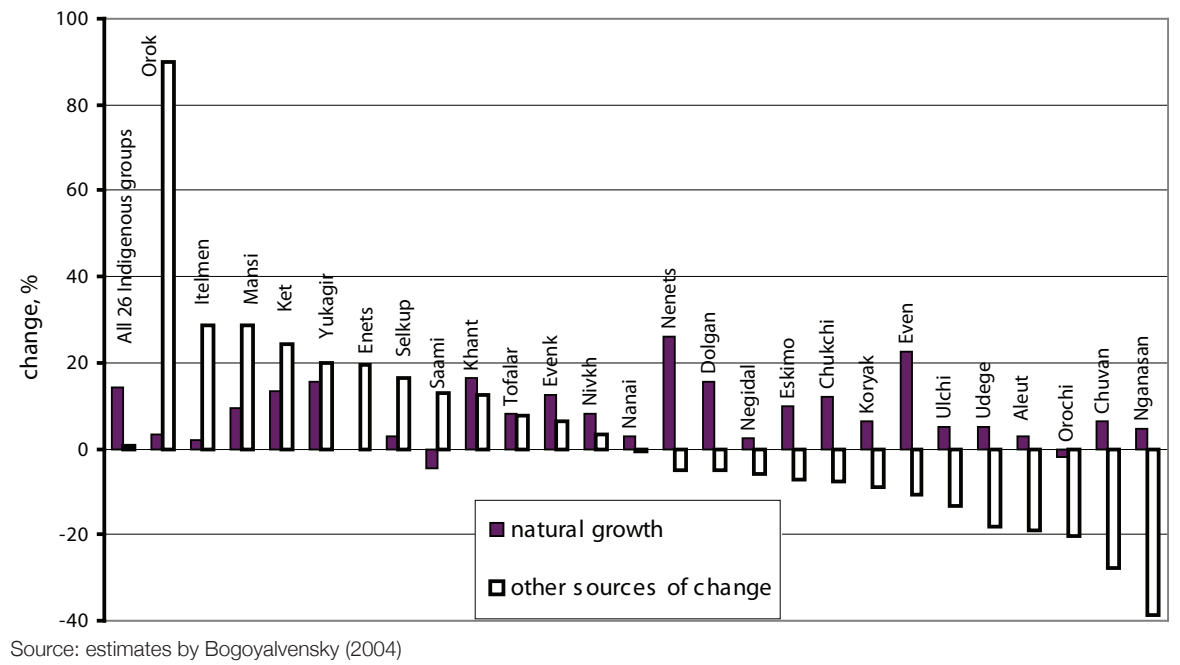

smaller INSPN, which experienced different degrees of "revival" in recent years (e.g., Saami). Other ethnic groups, especially living in oil-booming areas (e.g., Khant and Mansi), gained population from mass re-registrations amid the windfall of benefits for Indigenous peoples. ${ }^{9}$ Federal and regional laws supporting Native populations, passed in the 1990s, provided additional economic incentives for people to reclaim their Indigenous status. The estimated effect of nondemographic factors on population growth in 1989-2002 (Bogoyavlensky, 2004) was remarkable for large groups such as Khant (43.4\%), Evenk (34.5\%) and Mansi (75.3\%). Other important components of "nondemographic" change were legislative amendments (in particular, the legal recognition of certain ethnic groups as separate entities), as well as confusion and past errors in data collection (e.g., Enets vs. Nenets, Orok vs. Orochi, Even vs. Evenk).

Other INSPN, however, remained under strong assimilation pressure from both Russians and larger Indigenous groups (Figure 1). Available estimates (Bogoyavlensky, 2004) show that 14 Indigenous groups lost population to ethnic drift. Among them, 8 experienced net population loss between 1989 and 2002: Aleut, Eskimo, Orochi, Udege, Chuvan, Ulchi, Nganasan, and Koryak (Table 1). In all of these cases, the nondemographic loss overwhelmed natural growth, except for the Orochi,

natural growth included only Native homelands, and, thus, tends to underestimate population numbers, especially for certain ethic groups (e.g., Nanai, Udege). Consequently, this data should be used and interpreted with caution.

9. In post-Soviet Russia, people of mixed origin are granted an opportunity to freely change their "official" ethnicity (this was not the case in the USSR, where citizens had to permanently choose their "passport" ethnicity once, at the age of 16). A passage of new, more liberal, legislation by regional governments in some instances had an effect of a sudden surge in Indigenous population, similar to the aftermath of Bill C-31 in Canada. 
Table 2. Selected indicators of the Indigenous peoples living in homelands (in the North, Siberia and the Far East), Census 2002

\begin{tabular}{|c|c|c|c|c|c|c|c|c|c|}
\hline & $\begin{array}{c}\text { Population } \\
\text { change } \\
1989-2002 *\end{array}$ & $\begin{array}{c}\text { Births } \\
\text { per } 1,000 \\
\text { women }^{* *}\end{array}$ & $\begin{array}{c}\text { Urban, } \\
\text { \% }\end{array}$ & $\begin{array}{l}\text { Working } \\
\text { age, \% }\end{array}$ & $\begin{array}{c}\text { Employment } \\
\text { in land-based } \\
\text { economy, } \\
\%^{* * *}\end{array}$ & $\begin{array}{l}\text { Employment } \\
\text { in selected } \\
\text { modern } \\
\text { sectors, \% }\end{array}$ & $\begin{array}{l}\text { Employ- } \\
\text { ment } \\
\text { rate, \% }\end{array}$ & $\begin{array}{l}\text { No sec- } \\
\text { ondary } \\
\text { educa- } \\
\text { tion, \% } \\
\end{array}$ & $\begin{array}{c}\text { Ability } \\
\text { to speak } \\
\text { Native lan- } \\
\text { guage, } \%\end{array}$ \\
\hline Aleut & -16.1 & 1534 & 21.5 & 65.2 & 5.5 & 13.4 & 60.8 & 6.3 & 7.4 \\
\hline Chukchi & 4.4 & 2170 & 16.5 & 59.7 & 19.1 & 5.5 & 59.1 & 11.7 & 45.7 \\
\hline Chuvan & -21.5 & 1835 & 29.8 & 58.7 & 12.7 & 12.4 & 65.4 & 7.7 & 8.9 \\
\hline Dolgan & 10.3 & 2038 & 16.9 & 56.5 & 29.4 & 5.2 & 60.9 & 13.7 & 64.1 \\
\hline Enets & 19.7 & 1919 & 12.2 & 61.9 & 18.9 & 8.2 & 46.3 & 15.5 & 33.5 \\
\hline Eskimo & 2.7 & 1993 & 25.7 & 62.0 & 9.0 & 10.9 & 60.5 & 6.5 & 15.4 \\
\hline Even & 11.8 & 2256 & 31.3 & 58.3 & 12.9 & 6.6 & 52.8 & 10.4 & 32.6 \\
\hline Evenk & 18.8 & 2131 & 22.8 & 58.6 & 11.2 & 7.5 & 49.5 & 10 & 19.7 \\
\hline Itelmen & 30.9 & 1921 & 34.4 & 63.3 & 5.1 & 6.2 & 46.7 & 6.4 & 5.3 \\
\hline Ket & 37.8 & 2304 & 16.7 & 60.1 & 3.8 & 5.2 & 54.2 & 16 & 30.7 \\
\hline Khant & 28.7 & 2109 & 33.2 & 58.3 & 11.1 & 7.5 & 49.7 & 16.6 & 44.2 \\
\hline Koryak & -2.2 & 1953 & 28.6 & 61.3 & 9.8 & 7.3 & 44.4 & 12.1 & 29.3 \\
\hline Mansi & 38.1 & 1947 & 50.7 & 58.0 & 6.1 & 7.0 & 49.9 & 9.8 & 20.3 \\
\hline Nanai & 2.3 & 2130 & 28.3 & 64.1 & 7.5 & 4.7 & 40.0 & 8.5 & 26.5 \\
\hline Negidal & -3.4 & 2210 & 22.8 & 61.0 & 11.4 & 3.5 & 39.3 & 11.4 & 6.3 \\
\hline Nenets & 20.8 & 2494 & 17.0 & 53.2 & 25.7 & 4.7 & 48.2 & 25.7 & 70.7 \\
\hline Nganasan & -33.9 & 2158 & 18.1 & 56.5 & 18.6 & 3.9 & 42.2 & 13.2 & 50.1 \\
\hline Nivkh & 11.5 & 1986 & 46.7 & 62.9 & 9.8 & 5.1 & 48.2 & 10 & 9.8 \\
\hline Orochi & -22.3 & 1974 & 35.2 & 62.9 & 23.5 & 5.6 & 55.5 & 6.8 & 4.3 \\
\hline Saami & 8.5 & 1813 & 38.4 & 61.6 & 13.9 & 8.4 & 47.9 & 11.9 & 32.1 \\
\hline Selkup & 19.2 & 2152 & 15.9 & 61.9 & 12.2 & 8.8 & 40.9 & 18.5 & 30.7 \\
\hline Tofalar & 15.2 & 1917 & 5.8 & 63.2 & 3.7 & 3.5 & 19.3 & 19.2 & 15.8 \\
\hline Udege & -12.9 & 2298 & 22.0 & 63.2 & 12.3 & 3.6 & 44.2 & 13 & 9.1 \\
\hline Orok & 93.2 & 1748 & 56.7 & 65.8 & 12.2 & 5.1 & 34.4 & 9.4 & 3.7 \\
\hline Ulcha & -8.2 & 2121 & 15.2 & 61.3 & 8.5 & 11.2 & 37.0 & 14.5 & 13.4 \\
\hline Yukagir & 35.7 & 2277 & 42.0 & 57.1 & 12.5 & 6.6 & 63.2 & 8.1 & 27.5 \\
\hline
\end{tabular}

Notes: the table represents only 26 ethnic groups included in 1989 and 2002 Censuses (INSPN-26); * data for all Russia; ${ }^{* \star}$ calculated as the ratio between the total number of births and total number of women who reported having children (multiplied by 1,000), information for women 15 years of age and older; ${ }^{\star \star \star}$ - Land-based economy includes agriculture, hunting, fishing, forestry, and related industries. "Modern" sectors include administration, security, finance, real estate, business, social services, transport, construction and communication.

Sources: Rosstat, (2004b, vol.13), Sokolovski (2006).

who experienced natural decline in addition to ethnic drift. Assimilation tendencies will be considered in more detail in the following section on Indigenous languages. 


\section{Geographic Distribution: In Homeland in Minority}

Traditional areas of settlement (homelands) of the Indigenous peoples of the North are located in 25 regions of the Russian Federation (Figure 2, boundaries are given as of 2002). In contrast to other Arctic regions, and despite the vastness of Native homelands, the INSPN do not constitute a majority in any of these areas, including the Indigenous autonomous districts (okrugs), in which they are titular nations. Until January 1, 2007, there were seven such autonomous okrugs: Chukotskiy (of Chukchi), Evenkiiskiy (of Evenk), Koryakskiy (of Koryak), Khanty-Mansiiskiy (of Khant and Mansi), Nenetskiy (of Nenets), Taimyrskiy or Dolgan-Nenetskiy (of Dolgan and Nenets) and Yamalo-Nenetskiy (of Nenets). The Indigenous population exceeds $25 \%$ only in Koryakskiy (40.3\%) and Chukotskiy okrugs (30.7\%). The majority of population in northern regions is Russian, with substantial portions of Yakut, Buryat, Komi, and Karel in the Republics of Sakha-Yakutiya, Buryatiya, Komi, and Karelia respectively. The INSPN in many areas cannot even be considered a significant minority (Figure 2). On the other hand, they frequently constitute majorities in rural areas, whereas Russians typically dominate in cities. This urban-rural majority-minority divide, in conditions of urban primacy and rural isolation, poses significant challenges for the Indigenous peoples to assert their rights and make their voices heard.

Geographically (Figure 2), most Indigenous minorities are concentrated in the Republic of Sakha, Khabarovskiy kray and autonomous okrugs of West Siberia (each has over $10 \%$ of the total INSPN population). Note, however, that in any of these regions the share of the INSPN population is only in single digits. This spatial disparity (high concentration vis-à-vis small population shares) causes additional assimilation pressures on the Indigenous minorities. The process of amalgamating autonomous okrugs with neighbouring populous regions, now under way in Russia, is likely to exacerbate these problems (Evenkiiskiy, Taimyrskiy, and Koryakskiy okrugs were abolished in 2007).

\section{Fertility}

Indigenous fertility in the Russian North, in the last few decades, gradually declined. This is a common trend for Native peoples across the Arctic (Arctic Human Development Report [AHDR], 2004), most of whom exhibit receding crude birth and fertility rates. It is also generally consistent with the pattern of demographic transition. However, the fertility decline among the INSPN in the 1990s was exceptionally rapid and driven by socioeconomic cataclysms in the post-Soviet North (Fondahl, 1995; Semenov and Petrov, 2001). By the late 1990s, the crude birth-rate dropped to 17.6 per 1,000 from 30.2 in 1984-1988 (Bogoyavlensky, 1994 and 2004, data for 26 INSPN) or, according to a different account, from 31.9 in 1989 to 16.2 in 2003 (Klokov 
et al., 2004, includes 35 Indigenous peoples living in their homelands). Based on the annual statistics available for the Indigenous homelands only (Goskomstat Rossii, 1999; Rosstat, 2004a), during the late 1990s and early 2000s birth rates continued to fall, although at a modest pace. They dropped by about 3.0 points between 1996 and 2004, as the number of births continued to decline (Figure 3).

In comparative terms, the birth rate of the INSPN is below the Arctic average of 19.7 (AHDR, 2004). However, it is much higher than in the rest of Russia (10.2 in 2005, Rosstat, 2006). In fact, some INSPN are among the most "fertile" ethnic groups in the country (Table 2): Nenets, Even and Chukchi are among the top 20 in the number of children per woman $-2.5,2.3$, and 2.2 compared to just 1.4 for ethnic Russians (Rosstat, 2004b).

Similar to other Arctic regions (e.g., Romaniuc, 2003), there is evidence of links between the integrity of the traditional Indigenous culture (e.g., measured by the Native language proliferation) and higher fertility (Table 3). To a lesser extent, high Indigenous fertility can be associated with conditions of "underdevelopment," such as low levels of education and economic participation (particularly in "modern" industries) among Indigenous people, especially women. In fact, Indigenous northerners are among the least educated Russian citizens: $41.5 \%$ lack high school education

\section{Figure 2. Regional Distribution and Concentration of the Indigenous Numerically Small} Peoples of the North in 2002
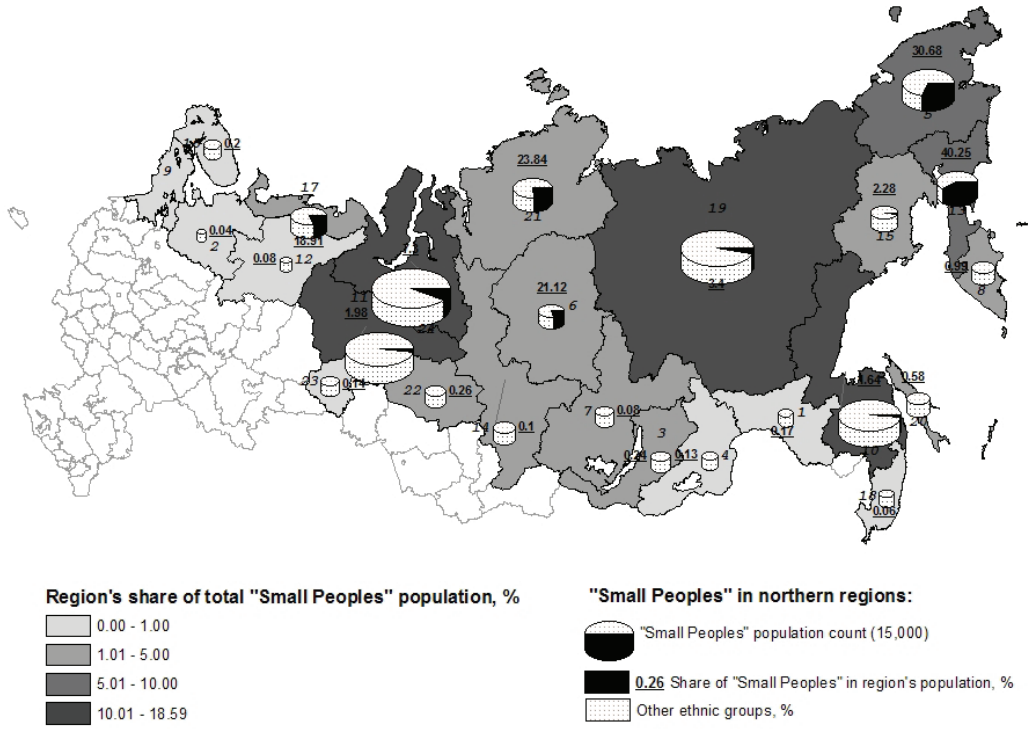

Source: Rosstat, 2004b)

Regions key (obl. - oblast', AO - autonomous okrug): 1 - Amurskaya oblast, 2 - Arkhangel'skaya obl., 3 - Republic of Buryatiya, 4 - Chitinskaya obl., 5 - Chukotskiy AO, 6 - Evenkiiskiy AO, 7 - Irkutskaya obl., 8 - Kamchatskaya obl., 9 - Republic of Karelia, 10 - Khabarovskiy kray, 11 - Khanty-Mansiiskiy AO, 12 - Republic of Komi, 13 - Koryaksky AO, 14 - Krasnoyarskiy kray, 15 - Magadanskaya obl., 16 - Murmanskaya obl., 17 - Nenetskiy AO, 18 - Primorskiy kray, 19 - Republic of Sakha, 20 - Sakhalinskaya obl., 21 - Taimyrskiy AO, 22 - Tomskaya obl., 23 - Tumenskaya obl., 24 - Yamalo-Nenetskiy AO. 
Table 3. Relationship between fertility, Native language proficiency and selected socioeconomic indicators

\begin{tabular}{|c|c|c|c|c|c|c|c|c|}
\hline & $\begin{array}{l}\text { Total } \\
\text { popula- } \\
\text { tion }\end{array}$ & $\begin{array}{l}\text { Urban, } \\
\%\end{array}$ & $\begin{array}{l}\text { Working } \\
\text { age, } \%\end{array}$ & $\begin{array}{l}\text { Employment } \\
\text { in land-based } \\
\text { economy, \% }\end{array}$ & $\begin{array}{l}\text { Employment } \\
\text { in selected } \\
\text { modern } \\
\text { sectors, } \%\end{array}$ & $\begin{array}{l}\text { No } \\
\text { secondary } \\
\text { education, } \\
\%\end{array}$ & $\begin{array}{l}\text { Ability to } \\
\text { speak } \\
\text { Native lan- } \\
\text { guage, } \%\end{array}$ & $\begin{array}{l}\text { Births } \\
\text { per 1,000 } \\
\text { women }\end{array}$ \\
\hline $\begin{array}{l}\text { Births per } 1,000 \\
\text { women }\end{array}$ & $.460^{*}$ & -.343 & $-.596^{\star \star}$ & .266 & $-.525^{\star \star}$ & .369 & $.485^{\star}$ & 1.000 \\
\hline $\begin{array}{l}\text { Ability to } \\
\text { speak Native } \\
\text { language, \% }\end{array}$ & $.525^{\star \star}$ & -.358 & $-.749^{\star \star}$ & $.611^{\star \star}$ & -.288 & $.624^{\star \star}$ & 1.000 & $.485^{\star}$ \\
\hline
\end{tabular}

compared to $22.4 \%$ in the federation (Rosstat, 2004b). Indigenous people, again especially women, are also less economically active and have fewer employment opportunities than the non-Indigenous population. According to the census (Table 2), the Aboriginal employment rate is only 52.0\% (Rosstat, 2004b). In addition, about $75 \%$ of Indigenous people are rural dwellers (Table 2).

Although the underlying reasons for high fertility among the Indigenous people in Russia are similar to Indigenous populations elsewhere, the nature of rapidly declining fertility of the INSPN is rather complex and, largely, is not attributable to the "conventional" drivers of the demographic transition (e.g. "modernization," improvements in family socioeconomic status, penetration of education, etc.), since none of these conditions can be observed. To the contrary, similarly to all Russia's citizens, Indigenous northerners were affected by the economic crisis that unfolded after the collapse of the USSR (Donskoy et al., 2001). Deteriorating economic wellbeing, diminishing social assistance, and a growing uncertainty in economic future forced families to engage coping mechanisms, including delaying or foregoing childbirth. The crisis was particularly severe in the North, where price hikes and shortfalls in goods, fuel, and food supplies (due to the failures of the centralized delivery system) were accompanied by backlogs in wage payments. The post-Soviet economic shock was an especially powerful factor in the early 1990s, when the Indigenous crude birth rate dropped from almost 40 to 26 per 1,000 over just a few years (Figure 3). However, studies demonstrated that purely economic factors did not entirely explain the overall fertility decline in the North (Petrov, 2006). Whereas the direct role of economic crisis was considerable, the decrease in fertility was also related to the rapid fertility transition amid deep changes in the traditional socioeconomic organization and existential conditions of Indigenous households.

The traditional division of labour and family organization of tundra reindeer herders, although substantially altered by Soviet economic reforms and forced sedentarization, were still partially preserved under the kolkhoz/sovkhoz system. Most families were still involved in nomadic or semi-nomadic reindeer herding, in which traditional roles of men and women were somewhat maintained (Klokov et al., 2004). Institutional reforms of the 1990s resulted in the quick erosion of this system, espe- 


\section{Figure 3. Crude birth and death rates (per 1,000) among the Indigenous numerically-small peoples of the Russian North in 1989-2004}
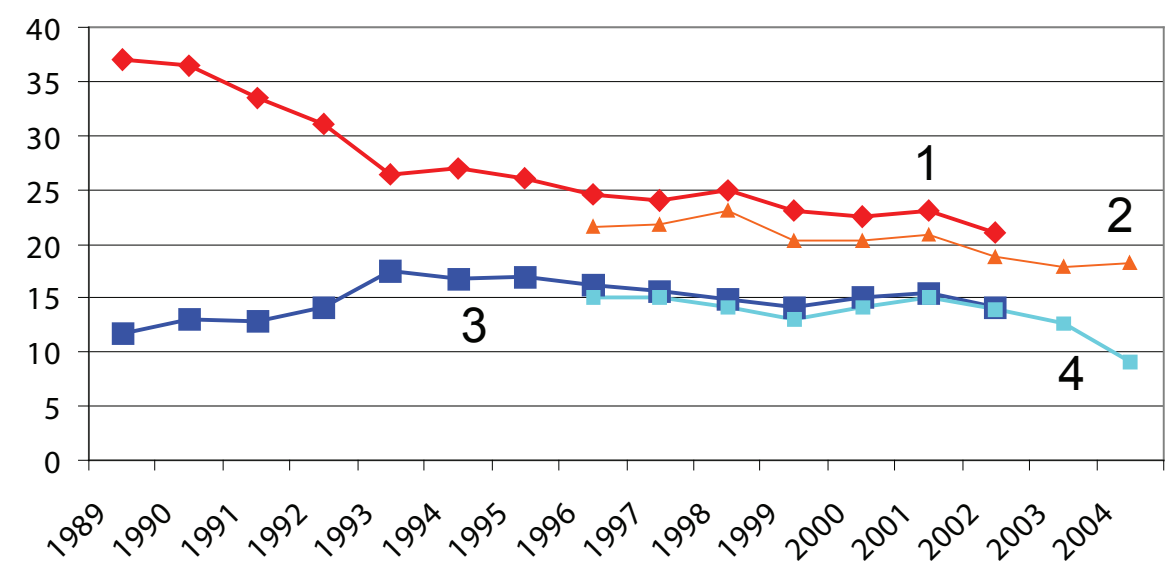

1 - crude birth rate for all INSPN-26 regardless of residence in 1989-2002 (an estimate by Bogoyavlenskiy, 2004);

2 - crude birth rate for INSPN-35 living in their homelands in 1996-2004 (Gokomstat Rossii, 1999; Rosstat, 2005);

3 - crude death rate for all INSPN-26 regardless of residence in 1989-2002 (an estimate by Bogoyavlenskiy, 2004);

4 - crude death rate for INSPN-35 living in their homelands in 1996-2004 (Gokomstat Rossii, 1999; Rosstat, 2005).

cially for some ethnic groups. Indigenous families had to adjust to a deteriorating economic situation and diminishing state subsidies. One of the ways to adapt was to resettle in villages and abandon reindeer herding in favour of more profitable employment for both genders. This move triggered fertility control mechanisms such as parity-related family limitation. Besides, the economic utility of children diminished in nonnomadic settings, while the cost of raising them increased. In other cases, even if a complete sedentarization was not the case, there was a change in labour (and family) relations between genders. Men tended to continue with nomadic reindeer herding, whereas women (whose labour has always been underpaid in the sovkhoz system) became more prone to stay and find an alternative job in villages, thus effectively separating Indigenous families. Both processes, of course, had a decisively adverse impact on fertility among Indigenous peoples, although they may also have contributed to declining infant mortality.

The connection between fertility and traditional lifestyles is also evidenced by higher fertility rates among the INSPN who managed to expand the traditional economy. Nenets is the case in point with $20 \%$ population growth, highest among the INSPN fertility, and successful family-based reindeer herding (Klokov et al., 2004). In addition, studies show a strong statistical relationship between traditional (nomadic) family reindeer husbandry, change in number of reindeers, and population dynamics of Indigenous ethnic groups (Khruschev and Klokov, 2001).

In sum, the rapid fertility transition among the Indigenous peoples was set off by a sudden economic crisis and institutional reforms, not by improving social and economic conditions. Changes in lifestyle and family behaviour, caused by the crisis, 
have long-term consequences. Even after the acute economic problems were partially resolved in the early 2000s (i.e., the direct impact of the crisis was lifted), birth rates of the INSPN failed to increase (Figure 3), indicating that the fertility transition is likely to be irreversible. This conclusion leads to a potentially paradoxical situation in the Indigenous demographic dynamic, in which the fertility transition is not accompanied by a mortality transition. In other words, falling fertility coexists with high mortality. Thus, the Indigenous population in the Russian North has experienced an unusual type of demographic transition, in which the decline in fertility outstrips the decline in mortality. If this distortion is not alleviated in the long term (i.e., mortality does not eventually decline), it may lead to a true demographic crisis and trigger depopulation.

\section{Mortality}

In the past three decades, Indigenous mortality in Russia was persistently high and was not declining, except for short periods - most remarkably in the late 1980s during the "anti-alcohol" campaign (Fondahl, 1995). This trend illustrates a stalled mortality transition and contrasts with other northern Indigenous nations, which have experienced steady declines in mortality since the 1960s (AHDR, 2004, Romaniuc, 2003). In 1989-2002 the Indigenous death rate in Russia increased by about 1.0 per 1,000 (see also Klokov et al, 2004), although by 2004 it receded to the pre-crisis levels (see Figure 3). The death rate peaked in the early 1990s (over 17.0 per 1,000!). Although mortality among the INSPN slightly declined during the early 2000s (Figure 3), it still drastically deviated from expected levels, given the young demographic structure of these ethnic groups. For the INSPS-26 living in their homelands, the average death rate in 1996-2004 was 13.6 per 1,000 (Rosstat, 2005) compared to just 4.3 per 1,000 in Nunavut (Statistics Canada, 2006) and around 8.0 in Greenland (AHDR, 2004).

An increasing death rate in the middle-age cohorts is closely related to the growth in unnatural causes of death among the INSPN during the 1990s. Including accidents, poisoning, injuries, suicides, and murders, these causes of Indigenous mortality reach $37 \%$ (as reported for the West Siberian nations, Bogoyavlensky, 2004). Ziker (2002) identified $60 \%$ of deaths in the Taimyr community of Ust'-Avam, between 1991 and 1997, as violent. This is true especially for Indigenous men of working age. Although unnatural causes are an important factor in Indigenous mortality elsewhere across the Arctic due to an array of social issues (e.g. Trovato, 2000, Romaniuc, 2003), their impact in Russia is much higher than anywhere else in the North (cf. in Greenland, 17.5\%; in Alaska, 24.6\%; in Canada, 22\%) (AHDR, 2004; Health Canada, 2000). Alcohol addiction frequently is the underlying reason for unnatural deaths, as well as a strong contributor to morbidity. Annually, over 2,500 residents of the Indigenous homelands are diagnosed with clinical forms of alcoholism (Rosstat, 2005). It has 
been speculated that as much as two-thirds of all deaths in some Indigenous homelands can be directly or indirectly attributed to alcohol-related causes (Anisimov, 2002).

High mortality in the young and middle age cohorts is associated with an extremely low life expectancy of Russia's Indigenous peoples. Even prior to the breakup of the USSR, Indigenous life expectancy was only about 60 years, at least 10 years shorter than the national average in 1989 (AHDR, 2004) and approximately 10 years less than the life expectancy of Native Canadians (Romaniuc, 2003). In the 1970-80s, by some accounts, the life expectancy of the Indigenous population in Russia (especially males) was as much as 18-20 years less than of the non-Indigenous northern population (Bakulin and Osipov, 1993). Thus, the life expectancy gap between the INSPN and the non-Native population in Russia/USSR was substantially wider than in other northern countries. Inadequate health care and social marginalization of Indigenous minorities have often been cited as major factors in the life expectancy differential.

In the post-Soviet period, the life expectancy of the INSPN declined even further. The socioeconomic crisis and the liberalization of hard liquor sales are strong contributing forces to this negative trend (Anisimov, 2002; Ziker, 2002). Some estimates suggest that the life expectancy of Indigenous northerners fell to 50 years by the mid-1990s (data for the Chukotka region, Chernukha et al., 2003; for the Evenkiya region, Anisimov, 2002), i.e., it returned to the 1979 level (AHDR, 2004). For example, in 2005 the life expectancy at birth of the predominantly Indigenous rural population in Chukotskiy okrug (Chukchi and Chuvan) was 50.8 years (46.9 for males and 55.4 for females) and in Koryakskiy okrug (mostly Koryak), 51.3 years (44.9 for males and 61.2 for females). The population of these two Indigenous homelands had the lowest life expectancy in Russia, 13 years below the nation's average (63.8) for rural populations (Rosstat, 2006).

A curious fact is that between 1989 and 2002 Indigenous infant death rates were in an unstable but persistent decline, while mortality in middle-age cohorts, especially among males, was on the rise. The drop in infant mortality from 41.1 in 1984-1988 to 27.6 per 1,000 in 1999-2002 (Bogoyavlensky, 2004), while good news certainly, does not look impressive, given that infant mortality is close to 10.0 in most Arctic regions outside Russia (AHDR, 2004). In remote northern autonomous regions (Chukotskiy, Koryakskiy and Evenkiiskiy okrugs) infant mortality rates were soaring up to 52.8 per 1,000 in 1997 (Goskomstat Rossii, 1999). The structure of infant death causes reflects a deep social crisis and the lack of childcare and medical services in the Russian North (Semenov and Petrov, 2001). Many areas have high rates of infant injuries and accidents, perinatal deaths, and respiratory diseases.

As a result of high death rates and rapidly falling birth rates, the natural growth among Indigenous minorities declined from 19.7 in 1984-1988 to 5.9 per 1,000 in 1999-2002 (Bogoyavlensky (2004) for INSPN-26) or to 6.1 for the INSPN-35, living in nonurban areas in their homelands (Rosstat, 2005). In other worlds, Indigenous 
minority groups experienced a three-fold reduction of natural growth over merely one decade. This demographic shock was instigated by dramatic social and economic challenges of the post-Soviet transitional period.

\section{Native Language Proficiency and Ethnic Drift}

It may be argued that Native language proficiency reflects the true level of belonging to Native cultures. The penetration of the Native language among people who claim Indigenous identity may be a good proxy of ethnic group's integrity and its capacity to withstand assimilation pressures. In this context, it is informative to analyze both the INSPN's proficiency in respective Native languages and in Russian - a dominant language of assimilation.

The census of 2002 indicated that the overwhelming majority of Indigenous peoples in the Russian North spoke Russian. The figure varied from $88.4 \%$ for Nenets to $95-100 \%$ for most Aboriginal nations (Rosstat, 2004b). Typically, almost $100 \%$ of the urban Indigenous population could speak Russian, whereas rural residents were noticeably less likely to be Russian speakers, although in all cases the percentage of Russian speakers exceeded $80 \%$. A strong penetration of the Russian language is, of course, not surprising given its dominant status in the education system, government, media, and other existential domains.

On the other hand, the 2002 census revealed that Aboriginal languages were fading. In 1989, about $65 \%$ of the Indigenous people (INSPN-26) indicated a Native language as their mother tongue (Tishkov and Stepanov, 2004); by 2002, only $38.5 \%$ reported an ability to speak the Native language of their ethnic group (see Table 1, although these data are only for Indigenous residents of the North, Siberia, and the Far East, and the language questions in 1989 and 2002 were formulated very differently). Smaller Indigenous groups demonstrated the poorest knowledge of a mother tongue. In 8 of them, less than $10 \%$ of population could speak their Native language in 2002 (e.g., Orok, Aleut, Negidal, Orochi, Itelmen), while virtually all representatives of these ethnic groups reported to be Russian speakers. These are clearly endangered languages spoken only by several dozens of people (e.g. Orok -11 , Orochi -18 , Aleut - 33 persons). However, the linguistic and cultural disintegration is not only a prerogative of the small INSPN. Only $19.7 \%$ of Evenk, second largest, although spatially dispersed ethnic group, spoke their mother tongue. This partially is due to a doubled assimilation pressure from both Russians and Yakut.

Table 3 indicates a positive and strong relationship $(r=0.61)$ between the level of engagement in a land-based economy and Native language preservation. Positive correlation with lowest levels of schooling reflects the destructive impact of the mainstream (Russian-based) education on Native languages. The negative relationship with the percentage of people in working age probably points to the effect of strong assimilation of these cohorts, born and educated in the Soviet period. More 
populous Indigenous peoples tended to maintain higher levels of Native language penetration than smaller ethnic groups $(r=0.53)$. However, there is no clear pattern indicating the relationship between Indigenous language proficiency and population dynamics.

Among ethnic groups with low numbers of Native speakers (below 20\%), there are two distinct categories: those that had population loss (e.g., Evenk, Udeghe, Chuvan, and Orochi) and those that experienced population gain (e.g., Orok, Itelmen, and Nivkh), both mostly due to ethnic drift. In the former case, the direction of the drift was towards assimilation, whereas in the latter case it was towards reclaiming the Indigenous identity and ethnic revival. In both cases, though, the population base of these ethnic groups is quite unsustainable, and the future of Indigenous cultures remains uncertain.

\section{Population Structure: Four "Lost" Generations}

The current population composition of the INSPN reflects two major processes of the Indigenous population dynamic: the demographic crisis (falling birth rates, increasing male and middle-age death rates, and low life expectancy) and the nondemographic change (assimilation or reclamation of the Indigenous identity). The Indigenous population structure, to some extent, mirrors the general patterns of demographic change in Russia (e.g., the baby-boom and echo waves). Population pyramids for northern Indigenous minorities (aggregated for INSPN-26) and Russia's total population are presented in Figure 4. Census 2002 data reveal noticeable dissimilarities (or anomalies) that make Indigenous nations distinct from the rest of the country's population. The following points are the most notable.

First, the population pyramid of the Indigenous population registers only a weak effect of the postwar baby-boom (40-55 years old cohorts). This anomaly may be explained by very high Indigenous infant and child mortality rates in the 1950 s and high contemporary death rates in these age cohorts. This generation, reaching their maturity in the 1970s, was deeply affected by assimilation, which was particularly strong in that period (Bogoyavlensky, 2004).

Second, there is a noticeable effect of social policies implemented in the 1980s. Improvements in social conditions, childcare, and economic well-being among the INSPN, coupled with the rapidly falling infant mortality and still soaring fertility, led to a strong showing of the second baby-boom wave. It is reflected in the high share of youth (10-19 years old). In fact, youngsters comprised $24.1 \%$ of Indigenous populations, compared to $16.0 \%$ in Russia (Figure 4). This wave in Indigenous cohorts would have been even more profound, had there been no assimilation.

Third, most Indigenous ethic groups are female-dominated. Women comprise $53.7 \%$ of the Indigenous population (vs. 53.4\% in Russia). Moreover, due to a sharp gender mortality differential, women prevail almost in all age cohorts starting at age 15 , despite substantially trailing boys in early childhood ( 952.5 girls per 1,000 
boys). A higher mortality of male children (mostly from unnatural causes, infectious and respiratory diseases) could be an explanation here. Note that in Russia, women start to dominate only in cohorts beyond 30 years old (still early compared to other developed countries). The INSPN clearly face a "male population crisis," both in young and middle-age cohorts. For example, the sex ratio in the $40-44$ cohort is $1,311.8$ women per 1,000 men. Indigenous communities lose their male population primarily because of devastating death rates. Indeed, the age-specific mortality of males between ages of 30 and 59 in Russia is three to five times as high as of females (Rosstat, 2004a). However, the degree of female dominance is different for different INSPN. The most distorted sex composition is found for Even, Negidal, and Nganasan (more than 1,250 females per 1,000 males).

One of the most revealing illustrations of demographic problems of the Russia's Indigenous peoples is the notion of "lost generations" clearly depicted in the age structure. The following analysis of population composition suggests distinguishing four "lost generations" of Indigenous northerners: "fading elderly" (over 60), "troubled middle age" (40-59), "runaway youth" (20-24) and "children of the crisis" (0-10).

\section{Lost Generation 1: Fading Elderly}

High mortality rates among the Indigenous groups have already been discussed earlier. Not surprisingly, the INSPN have a very limited number of elderly. In fact, according to the 2002 census, people over 60 years old comprise only $6.3 \%$ of the total Indigenous population, whereas at the national level this age group forms $21.0 \%$ of the population (Rosstat, 2004b). The age of 60 is beyond the Indigenous life expectancy line (see above). The Aboriginal elderly were apparently lost to severe conditions of life during their early years (in the 1930-1940s), to social marginalization of the 1950-1970s, and to the failure of the public health system in the 1990s. The "extinction" of the elderly is an extremely worrisome phenomenon, since it undermines the ability of northern peoples to carry on their Indigenous culture and traditions. Another important difference between the INSPN and the rest of Russia is the small number of surviving elderly women.

\section{Lost Generation 2: Troubled Middle Age}

Figure 4 clearly shows that Indigenous middle working age cohorts (40-59) appear to be underrepresented compared to the rest of Russia. A weak working age base is a troubling condition for ethnic groups with high dependency ratios (1.5-2.2 times the national average), such as northern Indigenous minorities (Klokov et al., 2004). Unfortunately, the middle-age cohorts are subjected to several major negative demographic factors: high mortality, particularly from unnatural causes (stemming from social marginalization, alcoholism, and criminalization), and the virtual absence of the first baby-boom wave. Indigenous males were more affected by high mortality than women mostly for social reasons (Klokov et al., 2004). This age group has also 
Figure 4. Population structure of the Russian Federation and the Indigenous Peoples of the North, Census, 2002

Indigenous peoples of the North

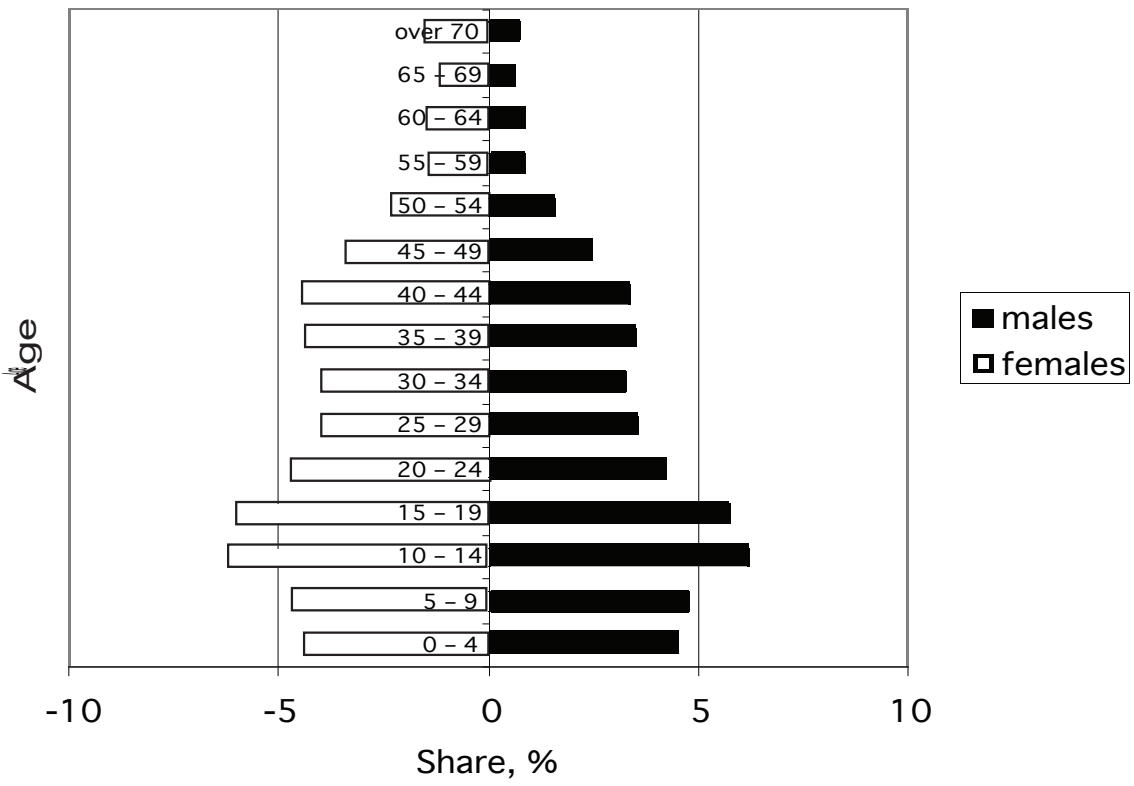

(Source: Rosstat, 2004b)

experienced considerable assimilation pressures. It is not an exaggeration to conclude that the Indigenous peoples experience the working age and male population crises.

\section{Lost Generation 3: Runaway Youth}

The next weak spot of the Indigenous age pyramid is in the cohorts of 20-29 years old. Unlike the national population structure, these cohorts are noticeably small, especially given high birth rates at the time of their entrance (although offset by high infant mortality). There may be several explanations to the relative weakness of the Indigenous youth. One deals with assimilation, because the 1970s and early 1980s were decades of increasing miscegenation, acculturation, migration to large cities, and russification (Bogoyavlensky, 2004). ${ }^{10}$ Therefore, children of that time could have been registered and raised as non-Indigenous people. Many were educated in boarding schools away from their families. In addition, the young northerners are exposed to assimilation by outmigrating for education or work. Departure in a search for new opportunities is instigated by the deep economic marginalization and scarce

10. For example, in the mid-1980s only $26.2 \%$ of children born in mixed Selkup-Russian marriages in Tumen' region were registered as Selkup. At the same time, $97.4 \%$ of all newly consummated Selkup marriages were ethnically mixed (Shargorodsky, 1994). 
job prospects in Indigenous homelands. However, this loss may have been partially compensated by the mass reclamation of Indigenous identity in some INSPN in the 1990s. To fully understand these trends, the "runaway generation" needs a further detailed study.

\section{Lost Generation 4: Children of the Crisis}

The most recent chapter in the history of the Indigenous peoples is associated with the unfolding socioeconomic crisis (Fondahl, 1995, Semenov and Petrov, 2001). Between 1989 and 2002, the natural growth in these ethnic groups was quickly falling, primarily due to declining fertility. Although birth rates of the INSPN remained greater than of non-Indigenous northerners and much greater than the Russian average, the dropping fertility marked potential problems in reproducing Indigenous populations, particularly combined with high mortality. The post-Soviet generation of Indigenous northerners is numerically smaller than it would have been, had the trend of the $1980 \mathrm{~s}$ been preserved. The severe economic crisis and growing social problems, as well an accelerated demographic transition, left the Indigenous populations with fertility levels below other Native peoples across the Arctic. In addition, the hardships of the 1990s eroded the social infrastructure, medical services, and childcare support. For example, at the peak of the crisis, northern regions of Russia saw closures of 139 obstetric care centres (1993-1996), 24 child policlinics (1994-1996), and a 20\% decrease of available spaces in pregnancy care facilities (Goskomstat Rossii, 2000b).

No doubt, the "children of the crisis" face additional challenges to ensure the survival of their ethnic groups. Although there are signs of the resurging Indigenous identity and the recognition of Indigenous cultural and educational rights (Federal'noye Sobranie RF, 1999), cultural, economic, and social emancipation of the Indigenous minorities is still an issue. As mentioned earlier, there is evidence of fading Indigenous languages amid depopulation among many Indigenous peoples.

\section{Conclusions}

It is not an exaggeration to say that the 2002 census revealed a troublesome trend in Indigenous demographics in the Russian North. Despite the Indigenous population growth between 1989 and 2002, Indigenous minorities experienced a true demographic crisis with a rapid fall of fertility and high mortality. Both of these trends, in this form and sequence, are contrary to demographic transition theory. They are also at odds with demographic trends registered in other parts of the Arctic. Much of the negative dynamic in the Russian North is directly attributed to dramatic economic, institutional, social, and cultural changes in the region after the collapse of 
the Soviet Union. Some of these changes were destructive to Native lifestyles and social well-being (and, in turn, to demographic trends), although others helped to raise the appreciation of Indigenous identify. Formidable social and economic challenges to Indigenous minorities are exacerbated by the deeply remote and isolated location of northern Aboriginal homelands (Figure 2). In addition, the ability of the INSPN to defend their rights and bargain for more privileges is undermined by their minority status in all northern regions, even where the Indigenous population is highly concentrated.

The Indigenous "numerically small peoples" require particular attention from the federal and regional governments. They need to be fully included in social, economic, and political processes, and to be provided with all means to continue their tradition and culture (Murashko, 2003). Indigenous minorities require special sociodemographic policies, which are yet to be developed. Maintaining traditional economy and lifestyle will achieve social justice and equality for the Indigenous peoples, and ensure their demographic viability, thus avoiding the "loss" of future generations of Indigenous northerners.

\section{Acknowledgements}

I would like to thank the editor and the anonymous reviewers for their valuable comments and suggestions.

\section{References}

Anisimov, N. 2002. "Spasti severyan ot vymiraniya" (Save northerners from extinction), Evenkiiskaya Zhizn' 58(8371), December 26.

AHDR. 2004. Arctic Human Development Report. Akureyri: Steffansson Arctic Institute.

Bakulin V.V. and V.A. Osipov. 1993. "Sovremennyi Geodemograficheskii Process Korennogo Naseleniya" (Contemporary geodemographic process of Indigenous population). Rossiya, Sever, More, $5^{\text {th }}$ Solovetskiy Forum: 42-44, Arkhandel'sk.

Bogoyavlensky, D.D. 1994. "Demograficheskie Problemy Malochislennykh Narodov Severa" (Demographic problems of the numerically small peoples of the North). Pp. 144-160 in A.G. Vishnevskiy (ed.), Naselenie Rossii 1994. Vtoroi Ezhegodnyi Demograficheskiy Doklad. Moscow: Evrasiya. - 2004. "Vymiraut li Narody Severa?" (Are northern peoples dying out?), Demoskop Weelky: 165166 (accessible at http://demoscope.ru/weekly/2004/0165/tema02.php\#4).

Chernukha, A.D., A.A. Chernukha, Y.P. Nikitin, and M.I. Voevoda. 2003. “Mediko-sotsial'nye i Demograficheskie Problemy Narodnostei Aziatskogo Severa" (Medico-social and demographic problems of the peoples of the Asian North). Problemy sotsial'noi gigieny, zdravookhraneniya $i$ istorii meditsiny 2:16.

Diatchkova, G. 2001. "Indigenous peoples of Russia and political history." Canadian Journal of Native Studies 21(2):217-233.

Donskoy, F.S, V.A. Robbek, and R.I. Donskoy. 2001. Korennye malochislennye narody Severa, Sibiri i Dal'nego Vostoka Rossiskoi Federatsii v pervoi chetverti 21 veka: Problemy i perspectivy (Indigen- 
ous Numerically Small Peoples of the North, Siberia and the Far East of the Russian Federation in the First Quarter of the 21st Century: Problems and Perspectives). Yakutsk: IPMNS SO RAN.

Federal'noe Sobranie RF. 1999. O Garantiyakh Prav Korennykh Malochislannykh Narodov Rossiiskoi Frderatsii (On the Guarantees of Rights of the Numerically Small Peoples of the Russian North). Federal Law adopted on 30.04.1999. Moscow.

Fondahl, G. 1995. "The status of Indigenous peoples in the Russian North." Post-Soviet Geography and Economics 36(4):215-284

Goskomstat Rossii, 2000. Rossiiskii Statisticheskii Ezhegodnik (Russian Statistical Yearbook) Moscow: Goskmostat. 2002. Metodologicheskie Voprosy Vasrossiiskoi Perepisi Naseleniya 2002 Goda T. 13 (Methodological questions of the 2002 All-Russia Population Census) Vol. 13. Moscow: Goskmostat.

1999. Sotsialno-ekonomicheskoe polizhenie v raionah prozhivaniya korennyh malochislennyh narodov Severa I priravnenny $k$ num mestnostyah (Socio-economic Situation in the Regions of the Habitation of the Indigenous Numerically-Small Peoples of the North and Equalized Areas). Moscow: Goskmostat.

Health Canada. 2000. A Statistical Profile on the Health of First Nations in Canada for the Year 2000. (http://www.hc-sc.gc.ca/fnih-spni/pubs/gen/stats profil e.html)

Heleniak, T. 1995. "Economic transition and demographic change in Russia, 1989-1995." Post-Soviet Geography and Economics 36(7):446-458.

- 2003. "The 2002 census in Russia: Preliminary results." Eurasian Geography and Economics 44(6):430-442.

Khruschev, S.A. and K.B. Klokov. 2001. Severnyi Nomadism v Rossii (Northern Nomadism in Russia). St. Petersburg: St. Petersburg State University Press.

Klokov, K.B., O.V. Petina, and S.A. Khruschev 2004. Semeinoye Domokhozyaistvo v Rayonakh Prozhivaniya Korennykh narodov Severa (Household Economy in the Regions of Habitation of the Indigenous Peoples). St. Petersburg: St. Petersburg State University Press.

Luffman, J. and Sussman, D. 2007. The Aboriginal labour force in Western Canada. Perspectives on Labour and Income, 8(1), 14-27.

Murashko, O.A. (ed.). 2003. Uchastie Korennikh Narodov v Politicheskoi Zhizni Stran Circumpolyarnogo Regiona: Rossiiskaya real'nost' $i$ Mezhdunarodniy Opyt (Participation of the Indigenous Peoples in the Political Life of the Circumpolar Countries). Moscow: International Work Group for Indigenous Affairs.

Petrov, A. 2006. Geopopulyatsionnye processy na Rossiiskom i Kanadskom Severe v 90e gody 20 veka (Geopopulation Processes in the Russian and Canadian North in the 90s of the 20th Century). St. Petersburg: Herzen State Pedagogical University of Russia.

Pika, A.I. and B.B. Prokhorov. 1988. "Bol'shie Problemy Malykh Narodov" (Big problems of small peoples). Kommunist 16:76-83.

Poelzer, G. and G. Fondahl. 1997. "Indigenous peoples of the Russian North: A decade of progress." Cultural Survival Quarterly 21(3):30-33.

RAIPON. 2007. Russian Association of Indigenous Peoples of the North. (http://raipon.org)

Romaniuc, A. 2003. "Aboriginal population of Canada: Growth dynamics under conditions of encounter of civilizations." Canadian Studies in Population 30(1):75-115. 
Rosstat, 2004a. Rossiiskii Statisticheskii Ezhegodnik 2004g (Russian Statistical Yearbook 2004). Moscow: Rosstat.

2004b. Vserossiiskaya Perepis Naseleniya. TT. 1-14 (All-Russia Population Census. Vol. 1-14). Moscow: Rosstat. (www.perepis2002.ru)

2005. Sotsialno-ekonomicheskoe polozhenie v raionah prozhivaniya korennyh malochislennyh narodov Severa i priravnennyh $k$ nim mestnostyah (Socio-economic Situation in the Regions of the Habitation of the Indigenous Numerically Small Peoples of the North and Equalized Areas). Moscow: Rosstat.

2006. Demograficheskii Ezhegodnik Rossii, 2006 (Demographic Yearbook of Russia, 2006). Moscow: Rosstat.

Semenov, S.P. and A.N. Petrov. 2001. "Demograficheskiy Krizis na Severe Rossii: Istoki i Geografiya" (Demographic crisis in the Russian North: Roots and geography). Izvestiya Russkogo Geograficheskogo Obshestva 133(3):89-91.

Shargorodsky, L.T. 1994. Sovremennye Etnicheskiye Protsessy u Sel'kupov (Contemporary Ethnic Processes of Selkup). Moscow: Institut Etnologii i Antropologii Rossiisskoi Akademii Nauk (Institute of Ethnology and Anthropology of the Russian Academy of Sciences).

Shnirelman, V.A. 1994. "Hostages of an authoritarian regime: The fate of the 'numerically small peoples' of the Russian North under Soviet rule.” Etudes Inuit Studies 18(1-2): 201-223.

Sokolovski, S. 2006. "Russian legal concepts and Indigenous peoples demography." Paper presented at the International Workshop Indigenous Identity in Demographical Sources. September 29-30, 2006. Umeå, Sweden: Umeå University.

Statistics Canada. 2006. Components of Population Growth, Canada, Provinces and Territories. Table 051-0004. Ottawa: Statistics Canada.

Tishkov, V. and V. Stepanov. 2004. "Rossiiskaya Perepis'v Etnicheskom Izmerenii” (Russian census in ethnic context). Demoskop Weelky 155-156 (accessible at http://demoscope.ru/weekly/2004/0155/ index.php)

Trovato, F. 2000. “Canadian Indian mortality during the 1980s.” Social Biology 47(1-2): 135-145.

Ziker, J. 2002. Peoples of the Tundra: Native Siberians in the Post Communist Transition. Prospect Heights, IL: Waveland Press, Inc. 